\title{
TOLERANSI ANTAR PENGANUT NAHDHATUL ULAMA, MUHAMMADIYAH, DAN KRISTEN JAWA DI BATANG
}

\author{
Adistya Iqbal Irfani, Moh. Yasir Alimi, Rini Iswari $\bowtie$ \\ Jurusan Sosiologi dan Antropologi, Fakultas Ilmu Sosial, Universitas Negeri Semarang, Indonesia
}

\section{Info Artikel}

Sejarah Artikel:

Diterima Desember 2012

Disetujui Januari 2013

Dipublikasikan Maret 2013

Keywords:

tolerance;

Nahdhatul Ulama;

Muhammadiyah;

Kristen Jawa.

\begin{abstract}
Abstrak
Tujuan penelitian ini adalah untuk mengeksplorasi bentuk toleransi dan faktor pendorong dan faktor penghambat toleransi masyarakat Jawa dengan studi kasus di Dukuh Medono Kabupaten Batang. Di dukuh tersebut, penganut organisasi agama seperti NU, Muhammadiyah dan Kristen Jawa di Dukuh Medono saling hidup rukun. Metode penelitian menggunakan metode penelitian kualitatif dengan pendekatan fenomenologi. Hasil penelitian menunjukan bahwa toleransi antar penganut NU, Muhammadiyah, Kristen Jawa tampak berbagai bentuk. Antara NU dan Kristen Jawa dalam bentuk partisipasi dalam ritual tahlilan, sedangkan antar ketiganya tampak dalam bentuk kerja bakti, saling membantu dalam acara hajatan, perkawinan campur dan saling berkunjung bila ada yang sakit. Faktor pendorong toleransi antara lain budaya toleransi yang sudah lama, pernikahan antar penganut yang berbeda, sosialisasi toleransi dalam keluarga, dan kepemimpinan desa yang menekankan pentingnya toleransi. Sedangkan faktor penghambat toleransi yaitu perbedaan pandangan antar penganut NU dan Muhammadiyah dalam pelaksanaan ibadah, pernikahan beda keyakinan, dan sikap menyinggung keyakinan diantara penganut yang ada.
\end{abstract}

\begin{abstract}
The objective of this study is to explore forms of tolerance and the driving factor of religious tolerance in Dukuh Medono, Batang. In that village, the followers of NU, Muhammadiyah, and Kristen Jawa live peacefully and united in tolerance. The research method used here is a qualitative method with phenomenology approach. The result of the research shows that the tolerance between NU followers and Javanese Christians take the form of participation in tahlilan ritual. The tolerance between NU, Muhammadiyah followers, and Kristen Jawa followers are expressed through kerja bakti, mutual support in hajatan rituals, mixed marriage, visits to the sick, and social activities together. The factors which help to create tolerance include the culture of tolerance which exist in the village, marriages between religious followers, the socialization of tolerance within family, the socialization of tolerance within the society and the role of village administrative leaders. On the other hand, the factors which distract tolerance are different point of view between NU dan Muhammadiyah followers in some religious aspects, marriage between different religious followers, and the attitude of insulting others beliefs.
\end{abstract}




\section{PENDAHULUAN}

Masyarakat Jawa identik dengan masyarakat yang plural. Keragaman ini salah satunya ditandai beragamnya keyakinan dan umat keagamaan yang dianut. Keberagaman umat keagamaan tersebut tersebar di berbagai bagian di Pulau Jawa, diantaranya di Kabupaten Batang. Di Batang terdapat berbagai organisasi Islam seperti Nahdhatul Ulama (NU), Muhammadiyah, Persis, dan LDII, dengan mayoritas berlatar belakang NU yang identik dengan Islam tradisional. Lokasi penelitian pada dukuh Medono, Desa Plumbon, Kecamatan Limpung, Kabupaten Batang. Dukuh Medono menjadi pilihan karena di dukuh ini pengikut NU dan Muhammadiyah hidup dalam suasana yang harmonis, dan bahkan kerukunan juga ditunjukkan umat Islam dan penganut Kristen Jawa.

Perbedaan dalam keyakinan dan doktrin antara penganut NU, Muhammadiyah, dan Kristen Jawa tidak menghalangi terjadinya keharmonisan dan gotong royong. Penganut NU, Muhammadiyah bahkan Kristen Jawa justru dapat saling bekerjasama dan tidak memandang status perbedaan agama yang dianut. Berdasarkan latar belakang di atas, penelitian ini bertujuan untuk menjawab dua pertanyaan utama: Bagaimana bentuk toleransi antar penganut Nahdhatul Ulama, Muhammadiyah, dan Kristen Jawa di Dukuh Medono? Faktor apa saja yang menjadi penghambat dan pendorong toleransi antar penganut Nahdhatul Ulama, Muhammadiyah, dan Kristen Jawa di Dukuh Medono?

Penelitian bertema toleransi beragama telah banyak dilakukan oleh para ahli. Penelitian tersebut antara lain penelitian yang dilakukan oleh Faridah (2009), penelitian ini mengkaji mengenai toleransi antarumat beragama dalam mengembangkan interaksi sosial warga masyarakat perumahan Penambongan di Kecamatan Purbalingga, Kabupaten Purbalingga. Toleransi masyarakat perumahan Penambongan terwujud dalam urusan agama dan toleransi sosial. Faktor pendorong toleransi masyarakat perumahan Penambongan seperti prinsip kerukunan, hormat, dan solidaritas, sedangkan faktor penghambatnya antara lain adanya konflik dalam bentuk persaingan dan rasa curiga terhadap kelompok agama lain. Toleransi beragama masyarakat perumahan Penambongan telah mendorong interaksi sosial yang baik dalam bentuk toleransi perkataan dan perbuatan sehingga terjadi kontak sosial dan komunikasi yang mendorong keakraban dan rasa persaudaraan.

Penelitian mengenai toleransi selanjutnya dilakukan oleh Rachmawati (2006). Penelitian ini mengkaji mengenai toleransi antar umat Islam dan Katholik di Dukuh Kasaran, Desa Pasungan, Kecamatan Ceper, Kabupaten Klaten. Hasil penelitian tersebut menunjukkan toleransi antar umat Islam dan Katholik di Dukuh Kasaran didorong oleh adanya faktor internal yaitu faktor keimanan, faktor pengalaman keagamaan, rasa tanggung jawab, dan faktor pengetahuan, serta faktor eksternal yaitu faktor keluarga dan faktor lingkungan masyarakat. Toleransi yang terbentuk pada masyarakat Dukuh Kasaran adalah berupa amalan-amalan dan perbuatan yang bersifat positif yang dipraktikkan dalam kehidupan sehari-hari untuk mewujudkan kerukunan antar umat beragama. Penelitian mengenai toleransi selanjutnya dilakukan oleh Puslitbang Kehidupan Beragama Kementrian Agama Republik Indonesia (2006) tentang toleransi dalam pandangan muslim mayoritas di Pandeglang. Pengetahuan masyarakat muslim Pandeglang tentang toleransi banyak dipengaruhi oleh nilai-nilai yang dianut bersama, terutama yang berasal dari agama.

Nilai-nilai tersebut sudah mentradisi dan diyakini secara turun temurun. Kelompok sosial yang paling berperan memelihara nilai-nilai itu adalah ulama, baik para kyai maupun jawara yang menjadi ustadz. Akibat adanya pandangan tersebut toleransi pada masyarakat muslim Pandeglang masih menjadi istilah sensitif, meskipun antara warga muslim yang mayoritas dan warga non-muslim yang minoritas sudah berbaur, namun apabila membicarakan masalah toleransi mereka sangat berhati-hati. Warga muslim lebih nyaman menggunakan istilah toleransi kewargaan daripada toleransi agama. Penelitian mengenai toleransi selanjutnya dila- 
kukan Ismail dalam Jurnal Analisa Volume XVII, No. 2, Juli-Desember 2010 yang berjudul Refleksi Pola Kerukunan Umat Beragama (Fenomena Keagamaan di Jawa Tengah, Bali, dan Kalimantan Barat) dengan hasilnya terdapat faktor-faktor yang bisa menjadi sarana atau wadah sosial terciptanya kerukunan atau toleransi keagamaan di Jawa Tengah, Bali, dan Kalimantan Barat yaitu tradisi atau adat budaya, tokoh agama, dan organisasi kelembagaan masyarakat atau pemerintah yang dapat diandalkan. Potensi kerukunan umat beragama sangat erat sekali dengan toleransi yang berada dalam ranah sosial, dimana masing-masing umat yang berbeda agama melakukan interaksi dalam kehidupan sosial mereka dan memang tidak perlu menyentuh ranah teologis. Ranah toleransi sosal inilah yang dipelihara, dijaga sebagai bentuk ruang dialog.

Penelitian ini memperkaya kajian tentang toleransi yang sudah dilakukan banyak sarjana dari berbagai pengalaman sosial yang berbeda-beda (Gole 2003, Habermas 2004, Jay 1982, Jha 2008, Matervski 2007, Mahlmann 2003, Muzaki 2010, Muchtar 2010, Randell-Moon 2009, Yonahan 2003 $\mathrm{mm} \mathrm{m}$ ) berdasarkan perspektif antropologi dan masyarakat Jawa. Berdasarkan beberapa tinjauan pustaka di atas penelitian ini akan membahas tentang toleransi antar penganut organisasi agama yang terjadi di kalangan penganut Nahdhatul Ulama, Muhammadiyah dan Kristen Jawa di Dukuh Medono, Desa Plumbon, Kecamatan Limpung, Kabupaten Batang. Toleransi inilah yang membedakan dengan penelitian sebelumnya, dimana sebagian besar penelitian tentang toleransi di ranah umat beragama, tetapi di dalam penelitian ini toleransi yang akan diteliti terfokus pada komponen yang lebih detail lagi yaitu toleransi yang terjadi antara penganut organisasi agama. Penganut Nahdhatul Ulama dan Muhammadiyah sebagaimana masyarakat pada umumnya banyak ditemukan masalah atau cara pandang yang berbeda dalam menjalankan kehidupan beragama sehingga sangat berpotensi terjadinya konflik. Fenomena itulah yang menjadi fokus dalam penelitian ini sehingga menjadikan penelitian ini berbeda dengan penelitian-penelitian sebelumnya.

Penelitian ini menggunakan konsep pluralisme dan toleransi. Pluralisme berasal dari bahasa Inggris yaitu pluralism yang berarti suatu kerangka interaksi tempat setiap kelompok menampilkan rasa hormat dan toleransi satu sama lain dan berinteraksi tanpa konflik atau asimilasi (pembauran/pembiasan). Pluralisme menurut Subkhan (2007) tidak hanya menunjuk pada kenyataan tentang adanya kemajemukan, namun yang dimaksud adalah keterlibatan secara aktif terhadap kenyataan kemajemukan tersebut. Konsep pluralisme agama yang dipakai dalam penelitian ini berasal dari Lubis (2007) yang menjelaskan pluralisme agama sebagai kondisi hidup bersama antar penganut agama yang berbeda-beda dalam satu komunitas dengan tetap mempertahankan ciri-ciri spesifik ajaran masing-masing agama. Dengan demikian yang dimaksud "pluralisme agama" adalah terdapat lebih dari satu agama (samawi dan ardhi) yang mempunyai eksistensi hidup berdampingan, saling bekerja sama dan saling berinteraksi antara penganut satu agama dengan penganut agama lainnya, atau dalam pengertian yang lain. Setiap penganut agama dituntut bukan hanya mengakui keberadan dan toleransi agama lain, tetapi juga terlibat dalam usaha memahami perbedaan dan persamaan demi tercapainya kerukunan dalam keragaman.

Konsep bentuk-bentuk toleransi yang akan dipakai dalam penelitian ini dari Yusuf (2002) yang membagi toleransi menjadi toleransi agama dan toleransi sosial. Toleransi agama menyangkut keyakinan atau akidah. Loyalitas dan keyakinan terhadap agama melahirkan dogma-dogma yang kebenaranya tidak dapat diganggu gugat meskipun bertentangan dengan rasio atau logika. Orang sering menganggap bahwa ajaran agama bersifat mutlak, dan kebenaran itu harus disampaikan kepada orang lain agar orang tersebut tidak sesat. Toleransi sosial disebut juga dengan toleransi kemasyarakatan karena toleransi tersebut menegakkan kedamaian hidup bersama dan melakukan kerjasama dalam batas-batas tertentu dalam masyarakat yang serba beranekaragam, baik ras, tradisi, keyakinan maupun agama. Toleransi 
tersebut dilakukan tanpa harus mengorbankan akidah dan ibadah yang telah diatur dan ditentukan secara rinci dan jelas.

Konsep mengenai faktor-faktor pendorong toleransi bersumber dari hasil penelitian Ismail yang mengkaji kerukunan atau toleransi keagamaan di Jawa Tengah, Bali, dan Kalimantan Barat yaitu tradisi atau adat budaya, tokoh agama, dan organisasi kelembagaan masyarakat atau pemerintah yang dapat diandalkan. Potensi kerukunan umat beragama sangat erat sekali dengan toleransi yang berada dalam ranah sosial, dimana masing-masing umat yang berbeda agama melakukan interaksi dalam kehidupan sosial mereka dan memang tidak perlu menyentuh ranah teologis. Faktor-faktor tersebut yang menjadi salah satu konsep dalam alat analisis hasil penelitian mengenai toleransi antar penganut Nahdhatul Ulama, Muhammadiyah, dan Kristen Jawa di Dukuh Medono, Desa Plumbon, Kecamatan Limpung, Kabupaten Batang. Toleransi dalam masyarakat sebagai sikap pencegah konflik senada dengan pandangan masyarakat Jawa mengenai rukun dan hormat. Prinsip kerukunan menurut Suseno (2001) adalah tidak mengganggu keselarasan sosial dan keselarasan pergaulan, sementara sikap hormat merupakan pada sikap dan perbuatan untuk dapat berbicara dan mampu membawa diri sesuai dengan derajat dan kedudukannya.

Prinsip kerukunan dan hormat tersebut sangat menekankan pada sikap dan perbuatan untuk menghindari konflik agar kehidupan masyarakat rukun dan harmonis. Sikap rukun yang dilakukan oleh masyarakat Jawa dapat berupa menghormati perbedaaan akibat pluralisme. Pluralitas dalam masyarakat Jawa juga dapat dilihat dari agama yang dianut. Agama dalam masyarakat Jawa sendiri sangat plural karena masyarakat Jawa menerima perbedaan agama itu sendiri dengan pemaknaan agama ageming aji yang mempunyai pemaknaan-pemaknaan didalamnya, salah satunya bahwa agama merupakan pedoman hidup yang pokok, artinya bahwa agama apa pun mengajarkan atau mengandung ajaran yang serba baik untuk keselamatan dan kesejahteraan hidup masyarakat di dunia ini (Damami, 2002 : 70-71).

\section{METODE PENELITIAN}

Penelitian menggunakan metode penelitian kualitatif dengan pendekatan fenomenologi. Metode penelitian kualitatif berlandaskan fenomenologi menuntut pendekatan holistik, mendudukan obyek penelitian dalam suatu konstruksi ganda, melihat obyeknya dalam satu konteks natural. Lokasi penelitian ini di Dukuh Medono, Kecamatan Limpung, Kabupaten Batang. Dukuh Medono memiliki masyarakat yang plural dengan adanya penganut NU, Muhammadiyah, dan Kristen Jawa. Perbedaan diantara ketiga penganut tersebut justru menyebabkan adanya toleransi yang tinggi untuk menjaga kerukunan dalam masyarakat sehingga penulis memilih Dukuh Medono dalam melakukan penelitian mengenai toleransi antar penganut NU, Muhammadiyah, dan Kristen Jawa. Lokasi penelitian di Dukuh Medono juga sangat mudah dijangkau oleh penulis karena lokasi tersebut berdekatan dengan desa tempat tinggal penulis sehingga sangat memudahkan penulis untuk memperoleh data penelitian yang dibutuhkan.

Subjek dalam penelitian ini adalah Bapak Lamsari dan Puryono selaku penganut NU, Bapak Susilo Darmawan,S.Pd.SD dan Muhadi selaku penganut Muhammadiyah, serta Bapak Bachri dan Jakiman selaku penganut Kristen Jawa. Pertimbangan untuk menentukan subyek penelitian tersebut bertujuan untuk saling memperkuat pernyataan antara subjek penelitian yang satu dengan subjek penelitian lainnya yang masih satu paham tersebut. Subjek penelitian pada umumnya penduduk asli Dukuh Medono meskipun beberapa subjek penelitian merupakan warga pendatang akan tetapi telah hidup lama di Dukuh Medono sehingga sudah banyak pengalaman dan mengetahui permasalahan yang sedang penulis teliti. Informan dalam penelitian ini antara lain Bapak $H$. Wahyudi selaku tokoh NU, Bapak Marjono selaku tokoh Muhammadiyah, Bapak Totok Pramono,S.Ag selaku tokoh Kristen Jawa, Bapak Eryanto selaku Kadus Medono, dan Bapak Kusnadi selaku Kepala Desa Plumbon. Pertimbangan penulis untuk menentu- 
kan informan untuk masing-masing organisasi NU, Muhammadiyah, dan Kristen Jawa sebanyak satu orang karena tokoh tersebu tmempunyai pengaruh yang besar bagi masing-masing penganut tersebut sehingga data yang diperoleh dapat lebih mendalam. Penulis menentukan informan tidak hanya Kadus Medono sebagai aparat desa yang bertugas di Dukuh Medono saja tetapi juga Kepala Desa Plumbon untuk memberikan data-data berupa wawancara sehingga dapat memperkuat data yang didapat penulis.

\section{HASIL DAN PEMBAHASAN}

Dukuh Medono secara administratif masuk dalam wilayah Desa Plumbon Kecamatan Limpung Kabupaten Batang. Dukuh Medono memiliki 5 RT yang terdiri dari RT 1, RT 2, RT 3, RT 4, dan RT 5. Dukuh Medono memiliki luas wilayah $490.718 \mathrm{Ha}$ dengan jumlah kepala keluarga $177 \mathrm{KK}$ yang terdiri dari laki - laki 357 orang dan perempuan sebanyak 368 orang, sehingga jumlah penduduk Dukuh Medono adalah 725 orang. Masyarakat Dukuh Medono mayoritas beragama Islam dengan jumlah 639 orang sedangkan pemeluk Kristen berjumlah 86 orang (data monografi Desa Plumbon, 2011:4).

Kerukunan beragama masyarakat Dukuh Medono berupa kondisi masyarakat yang beragam dalam hal organisasi keagamaannya. Masyarakat di Dukuh Medono yang beragama Islam terwujud dalam penganut NU dan Muhammadiyah, selain itu juga terdapat penganut Kristen Jawa. Data monografi Dukuh Medono menunjukkan mayoritas masyarakat memeluk agama Islam yang terdiri dari penganut NU sebagai kaum mayoritas dengan jumlah 575 orang dan penganut Muhammadiyah sebanyak 64 orang. Jumlah penganut Kristen Jawa di Dukuh Medono cukup banyak sehingga menempati urutan kedua dengan total penganutnya mencapai 86 orang.

Apa bentuk toleransi di Medono? Masyarakat Dukuh Medono memandang toleransi sebagai sebuah sikap dan perbuatan untuk dapat menjalankan kegiatan dalam kehidupan masyarakat secara bersama-sama tanpa membedakan agama atau organisasi yang dianut. Toleransi tidak hanya berupa sikap saling menghormati terhadap segala perbedaan yang ada diantara para penganut NU, Muhammadiyah, dan Kristen Jawa tetapi harus diwujudkan dalam bentuk kegiatan kemasyarakatan yang dilakukan secara bersama-sama. Pernyataan tersebut didukung dengan hasil wawancara yang diungkapkan oleh Bapak Bachri (60 tahun), penganut Kristen Jawa.

Ya dalam arti sosial kebersamaan toleransi itu kita saling merasakan apa yang dialami orang tersebut. Ya kita harus bersama dalam kegiatan sosial kemasyarakatan. Jadi kita menghadiri apa yang diselenggarakan umat Kristen atau Islam itu bentuk penghormatan saja bukan untuk ritual (Hasil wawancara pada tanggal 16 Juni 2012).

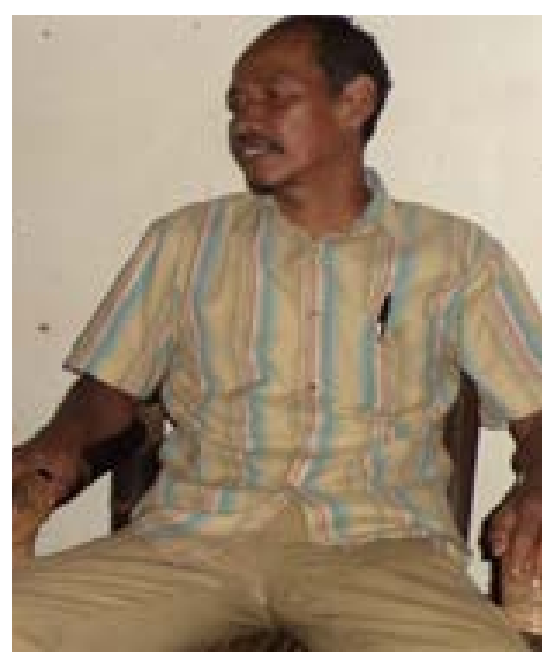

Gambar 1. Foto Bapak Bachri, penganut Kristen Jawa (Sumber : Dokumentasi pribadi, 16 Juni 2012).

Bentuk toleransi yang terdapat di Dukuh Medono antara penganut NU, Muhammadiyah, dan Kristen Jawa terwujud dalam kegiatan sehari-hari. Kegiatan seharihari yang termasuk toleransi sesuai dengan konsep toleransi yang dikemukakan Yusuf (2002), menurutnya bentuk toleransi terbagi menjadi dua macam yaitu toleransi agama dan toleransi sosial.

Bentuk toleransi agama yang terdapat di Dukuh Medono antara lain toleransi pada hari raya Idul Fitri berupa penganut 
NU dan Muhammadiyah dapat membaur dengan baik dalam halal bihalal, meskipun terkadang untuk pelaksanaan hari raya tidak bersama-sama karena penganut Muhammadiyah melaksanakan Idul Fitri biasanya lebih dahulu daripada penganut NU, selain itu penganut Kristen turut menyediakan makanan untuk menjamu penganut NU dan $\mathrm{Mu}-$ hammmadiyah dalam halal bihalal tersebut.

Telah juga tampak penganut NU dan Muhammadiyah saling bekerjasama dalam pembagian daging kurban pada waktu Idul Adha meskipun penyembelihannya terpisah. Kebersamaan antara penganut NU dan Muhammadiyah tidak hanya terlihat pada saat pembagian daging hewan qurban saja berlangsung melainkan juga pada saat pembagian zakat fitrah. Pembagian zakat fitrah berlangsung dengan baik dan dilandasi sikap toleransi yang cukup tinggi, ini terbukti dengan adanya pembentukan panitia zakat fitrah dengan melibatkan penganut NU dan Muhammadiyah.

Pada parayaan Natal penganut Kristen memberikan undangan kepada semua orang Islam untuk menghadiri perayaan Natal di gereja, akan tetapi penganut Muhammadiyah tidak berkenan hadir. Hal ini menyebabkan penganut NU yang berdekatan dengan gereja dan aparat desa setempat yang diundang saja yang hadir. Hal tersebut sesuai dengan hasil wawancara yang diungkapkan oleh Bapak Puryono (39 tahun), penganut NU.

Ya nek perayaan natalan teng gereja niku kula dateng Mas. Nyatane diundang kan tiyang $R T$ mriki ingkang caket gereja ya NU nopo $\mathrm{Mu}$ hammadiyah diundang tapi Muhammadiyah mboten kerso dateng tapi tetep rukun. Diundang ya kula kedah mangkat mas niku wujud ngormati tiyang Kristen. Ya walaupun teng mriku kula mung meneng mawonlah.

(Ya kalau perayaan Natal di gereja itu saya datang mas. Soalnya diundang yang orang RT sini yang dekat dengan gereja ya NU atau Muhammadiyah dapat undangan meskipun Muhammadiyah tidak berkenan hadir tapi ya tetap rukun. Diundang ya harus berangkat mas itu wujud menghormati orang Kristen. Ya walaupun di sana saya cuma diam saja (Hasil wawancara pada tanggal tanggal 16 Juni 2012).

Toleransi beragama juga dapat terlihat di masyarakat Dukuh Medono pada saat shalat Jum'at berlangsung. Penganut NU dan Muhammadiyah saling bergantian menjadi imam shalat jumat shalat jumat di Masjid An-Nur. Penganut NU maupun Muhammadiyah yang menjadi khatib khutbah shalat Jum'at berusaha tidak menyinggung kepercayaan masing-masing dalam hal ibadah.

Penganut NU apabila mengadakan tahlilan maka penganut Kristen Jawa ikut menghadiri dengan memakai pakaian seperti sarung dan peci seperti orang Islam. Penganut Kristen Jawa apabila mengadakan brayatan penganut NU juga menghadiri acara tersebut. Kegiatan tahlilan maupun brayatan penganut Muhammadiyah hanya sedikit yang berkenan menghadirinya. Kondisi tersebut sesuai dengan hasil wawancara dengan Bapak Susilo Darmawan,S.Pd.SD (53 tahun), penganut Muhammadiyah.

Ya kerukunan sini itu bentuknya barengbareng. Lha kalau ada orang yang meninggal Kristen ya sama disini 7 hari brayatan itu ya orang Islam juga dateng yang satu RT. Begitu juga sebaliknya ketika umat muslim ada tahlilan yang Kristen juga datang. Lha kalau Muhammdiyah ada yang meninggal ada yang tahlilan dan yang tidak. Yang tahlilan itu ya paling yang baru ya yang belum kuat lha kalau kaya saya yang sudah lama ya gak tahlilan. Ya kalau orang Kristen datang tahlilan ya gak bisa dibedain. Ya pake sarung pake peci sama pokoknya dengan orang muslim (Hasil wawancara pada tanggal tanggal $10 \mathrm{Mei}$ 2012).

Adanya keterbatasan ranah dalam hal keyakinan diantara penganut Nahdhatul Ulama, Muhammadiyah dan Kristen Jawa hal ini sesuai dengan konsep Lubis (2007) yang menjelaskan pluralisme agama adalah kondisi hidup bersama antar penganut agama yang berbeda-beda dalam satu komunitas dengan tetap mempertahankan ciri-ciri spesifik ajaran masing-masing agama. Pluralitas agama yang dimaksud adalah terdapat lebih dari satu agama (samawi dan ardhi) yang 


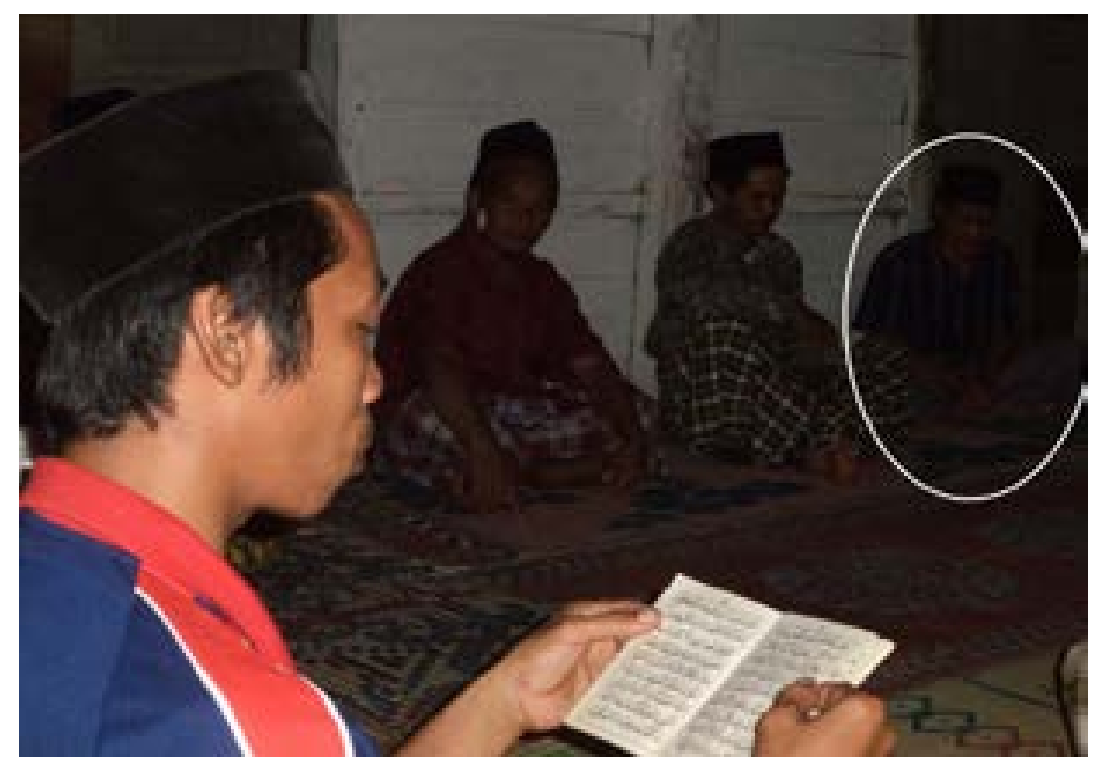

Gambar 2. Penganut Kristen Jawa (dalam lingkaran) di kegiatan tahlilan penganut NU (Sumber : Dokumentasi pribadi, 9 Mei 2012)

mempunyai eksistensi hidup berdampingan, saling bekerja sama dan saling berinteraksi antara penganut satu agama dengan penganut agama lainnya, atau dalam pengertian yang lain. Pemahaman mengenai toleransi tersebut dalam prakteknya di masyarakat toleransi mempunyai batasan ranah tersendiri yang tidak bercampur dengan keyakinan yang dimiliki masing-masing warga masyarakatnya. Kondisi yang demikianlah yang juga terjadi di masyarakat Dukuh Medono oleh para penganut NU, Muhammadiyah dan Kristen Jawa.

Toleransi sosial disebut juga dengan toleransi kemasyarakatan karena toleransi tersebut menegakkan kedamaian hidup bersama dan melakukan kerjasama dalam batas-batas tertentu dalam masyarakat yang serba beranekaragam, baik ras, tradisi, keyakinan maupun agama. Toleransi tersebut dilakukan tanpa harus mengorbankan akidah dan ibadah yang telah diatur dan ditentukan secara rinci dan jelas.

Bentuk toleransi sosial yang terdapat di Dukuh Medono antara lain apabila terdapat hajatan seperti pernikahan atau khitanan. Penganut NU, Muhammadiyah, dan Kristen Jawa di Dukuh Medono dapat saling membantu apabila mempunyai hajatan. Kebiasaan saling membantu tersebut sangat ter- lihat dalah hajatan pernikahan baik penganut NU, Muhammadiyah atau penganut Kristen sehingga hubungan masyarakat di Dukuh Medono toleransi dalam hal nikah sangat terasa sekali.

Toleransi sosial selanjutnya berupa kegiatan gotong-royong di Dukuh Medono yang diikuti pengikut NU, Muhammadiyah dan Kristen Jawa. Ketiganya dapat membaur menjadi satu pada saat gotong-royong seperti membersihkan makam atau jalan menuju makam. Kegiatan gotong royong membersihkan makam di Dukuh Medono dilakukan secara bersama-sama oleh ketiga penganut tersebut tanpa membedakan makam umat Islam atau Kristen Jawa. Hal ini sesuai dengan hasil wawancara dengan salah satu warga yaitu Bapak Totok Pramono (53 tahun), tokoh Kristen Jawa.

Ya kita harus bersama dalam kegiatan sosial kemasyarakatan termasuk dalam pemeliharaan dan pemakaman kita sama. Tidak ada istilah Kristen bersihkan kuburan sendiri Islam sendiri. Kita juga bersama dalam bersihkan jalan ke kuburan mas (Hasil wawancara pada tanggal tanggal 17 Mei 2012).

Gotong-royong atau kerja bakti juga dapat berupa perbaikan fasilitas umum yang 


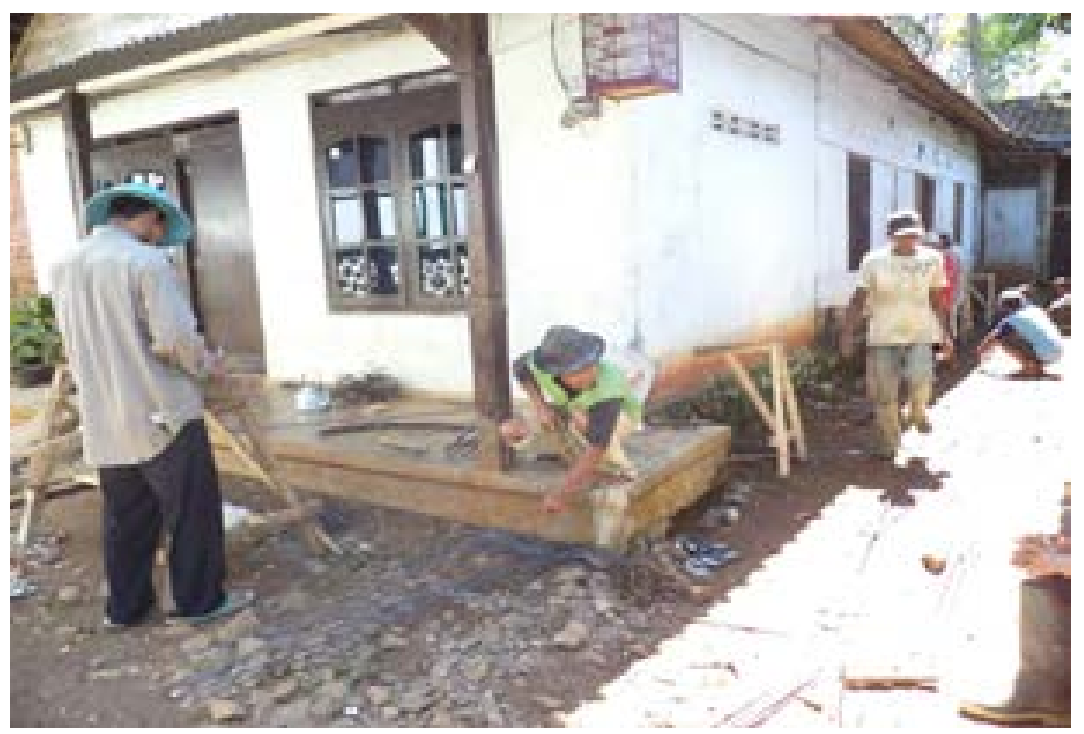

Gambar 3. Kegiatan kerja bakti atau gotong-royong memperbaiki Masjid An-Nur oleh masyarakat Dukuh Medono (Sumber : Dokumentasi pribadi, 16 Juni 2012)

terdapat di Dukuh Medono. Gotong royong tersebut dapat dilaksanakan lebih dari sehari atau dapat menentukan hari-hari tertentu untuk menyelesaikan perbaikan fasilitas umum yang ada. Kegiatan gotong-royong dapat terlihat salah satunya dalam kegiatan perbaikan tempat ibadah atau masjid. Perbaikan Masjid Baiturrahman dilaksanakan secara bersama-sama saling membantu antara penganut NU dan Muhammadiyah. Kegiatan gotong-royong secara bersama-sama dapat terlihat pada gambar 3 .

Selapanan RT atau rapat RT selain dihadiri oleh perangkat desa seperti Ketua RT setempat juga dihadiri oleh semua warga Dukuh Medono baik penganut NU, Muhammadiyah, dan Kristen Jawa sesuai dengan RT masing-masing. Kegiatan selapanan RT yang sangat berperan adalah para perangkat desa yang bertugas untuk memimpin jalannya rapat untuk membahas berbagai macam masalah desa yang perlu dicari solusinya secara bersama-sama dengan masyarakat setempat.

Toleransi sosial di masyarakat Dukuh Medono juga terwujud apabila ada salah satu warga yang menderita sakit. Penganut NU, Muhammadiyah dan Kristen Jawa akan saling menjenguk salah satu penganut organisasi yang sakit tersebut. Hal tersebut seperti dari hasil wawancara dengan Bapak
Puryono (39 tahun), penganut NU.

Menjenguk orang sakit ya tidak dibedabedakan. Orang Islam baik NU atau Muhammadiyah menjeguk orang Kristen yang sakit sudah biasa. Orang Kristen menjeguk orang NU atau Muhammadiyah yang sakit juga sudah biasa (Hasil wawancara pada tanggal tanggal 16 Juni 2012).

Berdasarkan atas konsep tentang pluralisme dan toleransi dalam penelitian ini yang menjelaskan bahwa pluralisme yang berarti suatu kerangka interaksi tempat setiap kelompok menampilkan rasa hormat dan toleransi satu sama lain dan berinteraksi tanpa konflik. Pluralisme menurut Subkhan (2007) tidak hanya menunjuk pada kenyataan tentang adanya kemajemukan, namun yang dimaksud adalah keterlibatan secara aktif terhadap kenyataan kemajemukan tersebut. Pluralisme yang dicerminkan dalam penelitian ini terdiri dari NU, Muhammadiyah dan Kristen Jawa. Pluralitas yang ada di Dukuh Medono tidak hanya menggambarkan adanya kemajemukan dalam penganut organisasi keagamaan saja melainkan juga terealisasi dalam sebuah dinamika sosial yang aktif yang terwujud dalam berbagai kegiatan masyarakat yang ada baik dalam ranah aga- 
ma maupun ranah sosial.

Toleransi yang terjalin di masyarakat Dukuh Medono juga tetap memunculkan konflik. Konflik yang terjadi berupa perpindahan agama tersebut dialami seorang perempuan penganut Muhammadiyah lulusan dari MA Muhammadiyah Limpung menikah dengan seorang laki-laki penganut Kristen. Penyelesaian konflik tersebut dilakukan dengan musyawarah antara tokoh Muhammadiyah, Kristen Jawa, dan dimediasi Kadus yang hasilnya karena pihak perempuan secara pribadi menyetujui untuk berpindah agama Kristen sehingga masalah atau konflik tersebut dapat terselesaikan dengan baik. Penyelesaian konflik tersebut yang lebih mendahulukan musyawarah menunjukkan bahwa masyarakat Dukuh Medono berusaha untuk menjaga toleransi yang telah terjalin dengan baik. Penjelasan tersebut sesuai dengan hasil wawancara dengan Bapak Marjono (60 tahun), tokoh Muhammadiyah.

Ya ada konflik kecil tapi yo selesai. Artinya gini ya belum lama ini masalah aqidah beda agama mau perjodohan. Orang Islam cewek lulusan MAM mau dapet cowok Kristen, nikah beda agama itu tidak boleh. Itu sempat kita dari Muhammadiyah diwakili saya, Pak Sus, dan Pak Sugeng pada waktu itu masih hidup orang Kristen itu ada Pak Totok, Pak Yunus, Pak Mul kita ketemu mediasinya adalah di tempat Kadus itu kita bicarakan. Tapi namanya anak sudah saling cinta ya monggo akhirnya masuk Kristen. Ya sudah tapi kita kan bertemu dimusyawarahkan dulu (Hasil wawancara pada tanggal tanggal 10 Mei 2012).

Konflik lain yang pernah terjadi di masyarakat Dukuh Medono dalam hal pengajian Muhammadiyah. Penganut Muhammadiyah mengadakan pengajian dengan pembicara mantan pendeta yang menjelekjelekkan Kristen. Para penganut Kristen Jawa yang mendengar merasa kegiatan yang dilakukan penganut Muhammadiyah tersebut justru akan memecah belah dalam masyarakat karena para penganut NU tidak pernah mengadakan pengajian yang menyinggung penganut Kristen Jawa.
Konflik dalam pengajian tersebut juga tidak sampai menjadi konflik terbuka diantara para penganut NU, Muhammadiyah dan Kristen Jawa, karena masing-masing penganut organisasi agama tersebut saling menjunjung tinggi sikap toleransi. Prinsip hidup masyarakat Dukuh Medono sama dengan prinsip hidup masyarakat Jawa yaitu rukun dan hormat. Toleransi dalam masyarakat sebagai sikap pencegah konflik merupakan prinsip kerukunan menurut Suseno (2001). Prinsip rukun adalah tidak mengganggu keselarasan sosial dan keselarasan pergaulan, sementara sikap hormat merupakan pada sikap dan perbuatan untuk dapat berbicara dan mampu membawa diri sesuai dengan derajat dan kedudukannya. Prinsip kerukunan dan hormat tersebut sangat menekankan pada sikap dan perbuatan untuk menghindari konflik agar kehidupan masyarakat rukun dan harmonis.

Sikap rukun yang dilakukan oleh masyarakat Jawa dapat berupa menghormati perbedaaan akibat pluralisme. Pluralitas dalam masyarakat Jawa juga dapat dilihat dari agama yang dianut. Agama dalam masyarakat Jawa sendiri sangat plural karena masyarakat Jawa menerima perbedaan agama itu sendiri dengan pemaknaan agama ageming aji yang mempunyai pemaknaan-pemaknaan didalamnya, salah satunya bahwa agama apa pun mengajarkan atau mengandung ajaran yang serba baik untuk keselamatan dan kesejahteraan hidup masyarakat di dunia ini (Damami, 2002 : 70-71).

Kondisi masyarakat yang masih dapat menjaga adanya toleransi dengan baik karena masyarakat Dukuh Medono juga merupakan masyarakat Jawa. Masyarakat Jawa adalah masyarakat yang plural. Konsep toleransi dalam masyarakat Jawa menurut Anderson (2000) menjelaskan toleransi masyarakat Jawa adalah penerimaan dan sikap hormat terhadap segala perbedaan selama tidak bertentangan dengan pandangan hidup masyarakat Jawa. Masyarakat Jawa mempunyai pandangan untuk selalu menjaga keselarasan hidup dan berusaha mencegah terjadinya konflik dalam masyarakat. Prinsip itulah yang juga sangat melekat di masyarakat Dukuh Medono sehingga toleransi 
diantara penganut yang berbeda yaitu NU, Muhammadiyah dan Kristen Jawa masih dapat berlangsung dengan baik.

Apa faktor pendorong dan penghambat toleransi di Medono? Faktor pendorong toleransi yang pertama antara penganut NU, Muhammadiyah dan Kristen Jawa adalah budaya toleransi dan saling menghormati yang sudah terjalin sejak dahulu. Masyarakat Dukuh Medono mempunyai tanggung jawab untuk terus menjaga dan melestarikan budaya toleransi ini dalam kondisi masyarakat yang plural, yaitu yang terdiri dari masyarakat penganut NU, Muhammadiyah dan Kristen Jawa. Masyarakat Dukuh Medono yang plural tersebut selau menjaga toleransi dalam berbagai bentuk kegiatan yang ada di masyarakat, meskipun pernah terjadi konflik namun masih dapat diselesaikan dengan baik sehingga kondisi masyarakat Dukuh Medono masih dapat terjaga kerukunannya. Hal ini sesuai dengan hasil wawancara dengan Bapak Eryanto (34 tahun), Kadus Medono.

Ya faktor pendorongnya karena memang ini sudah sejak lama kuat sekali sehingga kegiatan apapun dibuat pokoknya barengbareng. Tujuannya ya biar menjaga kerukunan Mas (Hasil wawancara pada tanggal tanggal 3 Mei 2012).

Faktor pendorong toleransi yang kedua berupa pernikahan. Di Dukuh Medono tidak ada pernikahan beda agama, tetapi baik penganut NU dan Muhammadiyah yang menikah dengan penganut Kristen salah satunya akan mengikuti keyakinan pasangannya. Perbedaan keyakinan dengan keyakinan keluarga sebelumnya yang ditinggalkan mendorong terjadinya toleransi dengan keyakinan baru yang dipeluk anggota keluarganya yang berpindah keyakinan tersebut. Faktor pendorong toleransi yang selanjutnya yaitu adanya sosialisasi toleransi dalam keluarga. Orang tua berperan dalam memberikan pengertian dan pemahaman bagaimana pentingnya toleransi itu, serta memberikan contoh dan penuturan dengan perlahan-lahan kepada anak agar anak dapat memahami serta mempraktikan langsung di kehidupan masyarakat.
Sosialisasi toleransi dalam masyarakat juga merupakan faktor pendorong terpeliharanya sikap toleransi di masyarakat Dukuh Medono. Sosialisasi toleransi di dalam masyarakat dilakukan oleh Kadus atau Ketua RT setempat dalam setiap rapat desa yang diadakan oleh masyarakat Dukuh Medono. Rapat desa yang masih sering dilaksanakan di Dukuh Medono biasanya disebut dengan selapanan RT. Selapanan RT diikuti oleh para penganut NU, Muhammadiyah dan Kristen Jawa. Kepala Desa Plumbon juga turut berperan dalam menjaga kerukunan di Dukuh Medono melalui himbauan dalam perayaan hari besar keagamaan dan nasional maupun kegiatan kemasyarakat lainnya. Pada kegiatan tersebut semua warga Dukuh Medono dapat berkumpul bersama sehingga para aparat desa menyampaikan beberapa pesan moral untuk tetap saling menjaga sikap toleransi antar sesama warga agar kerukunan dalam hidup bermasyarakat dapat tetap berjalan dengan baik. Hal ini sesuai dengan hasil wawancara Bapak Kusnadi (40 tahun), Kepala Desa Plumbon.

Saya sebagai kepala desa harus menjaga dan mendukung segala macam kegiatan kemasyarakatan yang positif termasuk kerukunan yang terjadi di Medono. Di setiap kesempatan saya dan aparat lainnya menghimbau masyarakat untuk saling menjaga kerukunan seperti perayaan hari besar atau kemasyarakatan. Kalau dalam selapanan RT itu aparat desa menyampaikan juga (Hasil wawancara pada tanggal tanggal 23 Mei 2012).

Tradisi toleransi yang telah terjalin sejak dahulu dan peran yang diperlihatkan oleh para perangkat desa sehingga toleransi antar sesama warga dapat terjalin dengan baik sesuai dengan hasil penelitian Ismail hasilnya terdapat faktor-faktor yang bisa menjadi sarana atau wadah sosial terciptanya kerukunan atau toleransi keagamaan di Jawa Tengah, Bali, dan Kalimantan Barat yaitu tradisi atau adat budaya, tokoh agama, dan organisasi kelembagaan masyarakat atau pemerintah yang dapat diandalkan. Potensi kerukunan umat beragama sangat erat sekali dengan toleransi yang berada dalam ranah 
sosial, dimana masing-masing umat yang berbeda agama melakukan interaksi dalam kehidupan sosial mereka dan memang tidak perlu menyentuh ranah teologis. Ranah toleransi sosial inilah yang dipelihara, dijaga sebagai bentuk ruang dialog. Adanya peran para tokoh masyarakat yang aktif sehingga mendorong penganut NU, Muhammadiyah atau Kristen Jawa di Dukuh Medono selalu mengikuti arahan dari para tokoh masyarakat untuk dapat menjaga toleransi dan hidup rukun melalui berbagai kegiatan kemasyarakatan yang positif. Kegiatan yang dapat menumbuhkah sikap toleransi antar sesama masyarakat terjalin dari berbagai kegiatan kemasyarakatan baik itu secara agama maupun sosial yang sudah turun temurun dari nenek moyang. Tradisi yang sudah turun temurun tersebut seperti menjalin silaturahmi saat hari-hari besar keagamaan, kegiatan kemasyarakatan gotong-royong, hajatan, selapanan RT dan lain sebagainya. Kegiatan baik itu dalam ranah agama maupun sosial bagi masyarakat Dukuh Medono merupakan sarana yang efektif untuk menjalin dan menunbuhkan sikap toleransi antar sesama dan menjaga kerukunan hidup beragama.

Faktor penghambat toleransi di Dukuh Medono antara lain perbedaan pandangan antara penganut NU dan Muhammadiyah dalam pelaksanan hal ibadah. Bentuk perbedaan tersebut antara lain berupa penganut Muhammadiyah tidak mengadakan tahlilan sedang penganut NU mengadakan tahlilan. Penganut Muhammadiyah maupun NU saling menyidir terhadap perbedaan diantara keduanya dalam kegiatan pengajian masingmasing. Sikap yang sangat fanatik terhadap praktik dalam beribadah yang berbeda tersebut tetapi tidak menimbulkan konflik terbuka dalam masyarakat. Hal tersebut sesuai dengan hasil wawancara yang diungkapkan oleh Bapak H. Wahyudi (64 tahun), tokoh NU.

Niku wujude selisih pendapat ya masalah $k a-$ dos tahlilan, Mas. Muhammadiyah mboten tahlilan NU nggeh. Kadang mriko ya nginceng-ngincenge pas dakwah nopo pas pengajian. Tapi kula ya nggeh nate mireng wonten saking NU kadang ya ngrasani Muhammadiyah, saking Muhammadiyah kadang ya ngrasani NU tapi ya mboten berlanjut crash.
(Itu wujudnya selisih pendapat ya masalah seperti tahlilan, Mas. Muhammadiyah tidak tahlilan NU iya. Kadang mereka ya melakukannya waktu dakwah atau pengajian. Tapi saya ya pernah mendengar dari NU kadang menyindir Muhammadiyah, dari Muhammadiyah kadang ya menyindir NU tapi ya tidak berlanjut konflik (Hasil wawancara pada tanggal tanggal 16 Juni 2012).)

Pernikahan selain menjadi faktor pendorong toleransi antar penganut NU, Muhammadiyah, dan Kristen Jawa di Dukuh Medono juga dapat menjadi faktor penghambat toleransi. Faktor penghambat tersebut berupa konflik akibat pernikahan antara perempuan penganut Muhammadiyah dengan laki-laki penganut Kristen Jawa yang menjadikan perempuan penganut Muhammadiyah tersebut menganut Kristen Jawa. Perpindahan keyakinan akibat pernikahan tersebut dilakukan secara damai melalui musyawarah dengan tokoh Muhammadiyah, Kristen Jawa, dan Kadus Medono, akan tetapi perpindahan keyakinan tersebut sebelum musyawarah dilakukan menimbulkan suasana yang tidak kondusif berupa perselisihan antara penganut Muhammadiyah dengan penganut Kristen Jawa di Dukuh Medono. Kejadian seperti ini akan sangat mempengaruhi toleransi antar penganut NU, Muhammadiyah, dan Kristen Jawa yang telah terjalin dengan baik di Dukuh Medono.

Sikap yang menyinggung keyakinan antar penganut menjadi faktor penghambat yang tidak akan pernah lepas di dalam masyarakat. Bentuk sikap tersebut terjadi pada waktu pengajian Muhammadiyah dengan pembicara mantan pendeta Kristen yang mengungkapkan kejelekan keyakinan Kristen. Pernyataan tersebut didukung dengan hasil wawancara yang diungkapkan oleh Bapak Jakiman (51 tahun), penganut Kristen Jawa.

Ya wau niku mas moyoki keyakinan piyambak-piyambak kados pas pengajian Muhammadiyah wau. Niku saged ngrusak kerukanan teng mriki.

(Ya tadi itu Mas meyindir keyakinan 
sendiri-sendiri seperti waktu pengajian Muhammadiyah tadi. Itu bisa merusak kerukunan di sini (Hasil wawancara pada tanggal tanggal 16 Juni 2012).)

Berbagai faktor yang mendukung atau bahkan menghambat toleransi antar penganut NU, Muhammadiyah, dan Kristen Jawa di Dukuh Medono, menjadi tantangan tersendiri bagi masyarakat yang bersifat plural dalam segi organisasi agamanya untuk dapat tetap hidup berdampingan dan menjaga kerukunan hidup yang ada. Toleransi antar penganut NU, Muhammadiyah, dan Kristen Jawa yang sudah terjalin dengan harmonis di Dukuh Medono harus tetap dijaga dalam kehidupan. Para penganut NU, Muhammadiyah, dan Kristen Jawa harus saling bertoleransi dan harus bersikap bijak dalam menyikapi segala bentuk perbedaan untuk mewujudkan kerukunan dalam masyarakat.

\section{SIMPULAN}

Penganut NU, Muhammadiyah, dan Kristen Jawa di Dukuh Medono memandang toleransi tidak hanya berupa sikap saling menghormati tetapi harus diwujudkan dalam bentuk kegiatan kemasyarakatan yang dilakukan secara bersama-sama. Kegiatan kemasyarakatan tersebut telah lama dibudayakan sebagai suatu cara untuk menjaga toleransi di Dukuh Medono.

Bentuk toleransi antar penganut NU, Muhammadiyah dan Kristen Jawa terbagi menjadi dua macam yaitu toleransi agama dan toleransi sosial. Bentuk toleransi agama antara lain penganut NU dan Muhammadiyah saling bertoleransi dalam merayakan Idul fitri meskipun kadang berbeda hari rayanya; penganut Kristen Jawa turut serta merayakan Idul Fitri dengan menyediakan makanan dan minuman dalam acara halal bihalal; penganut NU dan Muhammadiyah bekerjasama dalam pembagian daging kurban dan kegiatan zakat fitrah; penganut Kristen Jawa dalam merayakan Natal juga dihadiri penganut NU yang berdekatan dengan gereja dan aparat desa setempat; penganut NU dan Muhammadiyah yang menjadi khatib khutbah shalat jum'at berusaha tidak menying- gung kepercayaan masing-masing dalam hal ibadah; kegiatan tahlilan penganut NU maka penganut Kristen Jawa ikut menghadiri dengan memakai pakaian seperti sarung dan peci dan apabila penganut Kristen Jawa mengadakan brayatan penganut NU juga menghadiri acara tersebut, sedangkan penganut Muhammadiyah hanya sedikit yang menghadiri tahlilan dan brayatan. Bentuk toleransi sosial antara lain saling membantu apabila ada penganut NU, Muhammadiyah, dan Kristen Jawa yang mempunyai hajatan; saling bekerjasama membersihkan jalan menuju makam dan makam; selapanan RT; dan saling menjeguk antar penganut $\mathrm{NU}, \mathrm{Mu}-$ hammadiyah, dan Kristen Jawa yang sedang sakit.

Faktor pendorong toleransi antar penganut NU, Muhammadiyah, dan Kristen Jawa di Dukuh Medono antara lain budaya toleransi yang terjalin sejak lama berupa saling bekerjasama dalam berbagai kegiatan; pernikahan antar penganut NU, Muhammadiyah, Kristen Jawa, sosialisasi toleransi dalam keluarga oleh orang tua kepada anak; dan sosialisasi toleransi dalam masyarakat oleh para aparat desa. Faktor penghambat toleransi antara lain perbedaan pandangan antara penganut NU dan Muhammadiyah dalam pelaksanan hal ibadah seperti tahlilan; pernikahan beda keyakinan; dan sikap yang menyinggung keyakinan antar penganut.

\section{DAFTAR PUSTAKA}

Alimi, M.Y. 2012. Catatan Editor: Kearifan Lokal untuk Hidup yang Lebih Baik. Jurnal Komunitas.4(1)

Anderson, B. R. O'G. 2000. Mitologi dan Toleransi Orang Jawa. Yogyakarta : Qalam.

Cantor, David.2004. The religious right: The assault on tolerance \& pluralism in America. New York: AntiDefamation League.

Damami, M. 2002. Makna Agama Dalam Masyarakat Jawa. Yogyakarta : LESFI.

Faridah, I.F. 2009. 'Toleransi Antar Umat Beragama dalam Mengembangkan Interaksi Sosial Warga Masyarakat Perumahan (Studi Kasus di Perumahan Penambongan Kecamatan Purbalingga Kabupaten Purbalingga)'. Skripsi : Semarang : FIS Unnes.

Gole, N. 2003. Contemporary Islamist movements and new sources for religious tolerance. Journal of Human Rights. 2 (1): 17-30. 
Hilman, L. 2003. Toleransi dalam interdiskursus teks sastra. Sosial Humaniora. 7 (2): 100-115.

Habermas, Jürgen.2004. Religious Tolerance-The Pacemaker for Cultural Rights, Philosophy . Cambridge: Cambridge University Press 2004

Ismail, A. 2010. Refleksi Pola Kerukunan Umat Beragama (Fenomena Keagamaan di Jawa Tengah, Bali, dan Kalimantan Barat). Jurnal Analisa. $17(2): 175-186$

Jay, N. 1982. Foundations of religious tolerance,. Toronto: Toronto Uni Press

Jha, S. 2008. Trade, Institutions and Religious Tolerance: Evidence from India. Stanford University Graduate School of Business Research Paper No. 2004

Lubis, A. K. 2007. Islam dan Pluralisme Agama. http:// www.scribd.com/ doc/82968981/Islam-DanPlural-is-Me-Agama-2. (22 Jan. 2012)..

Matervski, Z. 2007. Religious Dialogue And Tolerance - Theoretical And Practical Experiences Of Differences And Similarities. The Politics and Religion Journal. Issue 1.

Mahlmann, M. 2003. Religious Tolerance, Pluralist Society and the Neutrality of the State: The Federal Constitutional Court's Decision in the Headscarf Case. Public Law. 10 (2): 202-212.

Muzaki. 2010. Partisipasi Tokoh Masyarakat dalam Toleransi Umat Beragama. Komunika. 4 (2): 296-313
Muchtar, B. 2012. Dalam Praktek, Masyarakat Indonesia Tak Toleran. Jurnal Todupoli. Edisi Pebruari 2012.

Puslitbang Kehidupan Beragama Kementrian Agama Republik Indonesia. 2006. 'Toleransi dalam Pandangan Muslim Mayoritas di Pandeglang'. http://balitbangdiklat.kemenag.go.id/(22 Jan. 2012).

Rachmawati, A. F. D. 2006. 'Toleransi antar umat Islam dan Katholik di Dukuh Kasaran, Desa Pasungan, Kecamatan Ceper, Kabupaten Klaten'. http://digilib.sunan-ampel.ac.id/index.php (22 Jan. 2012).

Randell-Moon, H. 2009. Tolerating Religious 'Others': Some Thoughts on Secular Neutrality and Religious Tolerance in Australia. Australian Religion Studies Review. 22 (3): 10-20.

Suseno, M. F. 2001. Etika Jawa Sebuah Analisa Falsafi Tentang Kebijaksanaan Hidup Jawa. Jakarta: PT. Gramedia.

Subkhan, I. 2007. Hiruk Pikuk Wacana Pluralisme di Yogyakarta. Yogyakarta : Kanisius.

Yusuf, A. A. 2002. Wawasan Islam. Bandung : Pustaka Setia.

Yonahan, F. 2003. Tolerance and Coercian in Islam: interfaith Relations in Muslim Tradition. Cambridge: Cambridge University Press. 